\title{
Something Old, Something New?: Competing logics and the hybrid nature of new
} corporate professions

\begin{abstract}
The professionalisation of certain management occupations, such as Project Management and HRM, has been neglected in recent debates on professions, which instead focus upon the de-regulation of collegial professions or the failure or unwillingness of new expert occupations to professionalise. Project management represents one of a handful of 'management professions' which confound this interpretation, explicitly pursuing a 'corporate professionalisation' project with some degree of success. This article focuses on the strategic activities of the principal British professional association in this field, the Association for Project Management (APM), as it negotiates a path between exploiting established sources of legitimacy and exploring a novel conception of professionalism. In the process, the association manipulates collegial and corporate logics of professionalism, in terms of its relationships with key stakeholders, its global orientation, its knowledge base and strategies of occupational closure. Drawing on interviews with APM officials and broader documentary analysis, this article analyses the conditions which have produced this hybrid model of professionalism, highlighting the pragmatic management of tensions through the combination of distinct, even contradictory, professionalisation logics.
\end{abstract}

\section{Introduction}

To rescue the legitimacy of management in contemporary society, there have in recent years been renewed calls for its establishment as a profession; self-regulating, socially responsible and committed to an ethical code (Khurana and Nohria, 2008). Little progress is apparent in the professionalisation of general management in the last century, with Reed and Anthony pointing to "formidable - some would say insurmountable - obstacles that stand in the way of managerial professionalization" (1992: 598). Despite this, a number of management's sub-disciplines, such as HRM (Wright, 2008), advertising (McLeod et al, 2011), strategy (Whittington et al, 2011; Noordegraaf et al, 2014), consulting (Sturdy, 2011), marketing (Walker and Child, 1979; Enright, 2006), public relations (Edwards, 2014) and project management (Hodgson, 2002), have indeed made strides towards professional self-organisation and the achievement of some form of professional recognition.

How such managerial occupations professionalise, and indeed why they might wish to, are difficult questions, particularly in the current institutional context which is seen to be particularly hostile towards professionalism (Reed, 1996; Broadbent et al, 1997; Hanlon, 1998). Professionalism, with its 
reliance on perceived anachronisms such as monopolistic closure, restricted practice and selfregulation, is seen by many as no longer desirable or achievable for any occupation (Muzio et al, 2007). The question is more acute for management occupations, with many suggesting that management and professionalism are fundamentally distinct occupational logics and work organization methods (Freidson, 2001; Ackroyd, 1996; Ackroyd and Muzio, 2007). Despite all of this, the cachet of the title of 'professional' seems to retain attraction for a number of specialist managerial disciplines. Striving for the legitimacy that traditional professions like medicine and law enjoy (or have enjoyed in the past), several contemporary management occupations are staging their own professionalization projects (Kipping et al, 2006; Muzio et al, 2007; Muzio et al, 2011; Sturdy et al, 2013; Thomas and Thomas, 2014).

This article explores the professionalisation of management specialisms through an examination of the case of project management, which has enjoyed a significant period of expansion and, as indicated by the recent award of a Royal Charter, some considerable success against its occupational objectives. In this context, we analyse the novel and distinctive professionalization strategies deployed by the dominant association for this occupation in the UK, the Association for Project Management (APM). We do so by engaging with the literature on corporate professionalism (Muzio et al, 2011; Paton et al, 2013; Thomas and Thomas, 2014) which we develop by highlighting how contemporary professionalization projects are not so much characterised by a shift from collegial to corporate logics but by the ability to opportunistically draw on and recombine elements of these distinctive logics to create a hybrid form of professionalism. As such, rather than reproducing idealised models of professionalism (Fincham, 2012), this research highlights the work required to balance and reconcile competing logics of professionalism and the competing interests of key stakeholders (Kodeih and Greenwood, 2014), in particular those of the large corporations who are the main employers and consumers of specialist managerial expertise including project management (Veldman, 2013; Paton et al, 2013). In doing so, we make a number of contributions towards better understanding the nature of professionalism and the prospects of professionalization in the contemporary era. In particular, with reference to other knowledge-based and managerial occupations, our case study indicates how successful professionalization projects might be connected to the ability of professional associations to balance different professional logics and their respective strategies and tactics and to manage the hybrid models of professionalization that result from this.

The article is organised as follows. First, we review the literature on professions identifying the key features of collegial forms of professionalism and contrasting these with organizational and marketbased models (Reed, 1996; Fincham, 2006), which characterises new forms of expertise as radical 
departures from the collegial professions. Between these positions, we analyse the emergence of corporate professionalism (Kipping et al, 2006; Muzio et al, 2011; Paton et al, 2013) and consider the rise of project management as an example of a corporate profession. We then explore, drawing on interviews with APM senior officials and the analysis of APM documentation published since 2001, the particular professionalisation strategy adopted by the APM and present its defining characteristics. Our analysis highlights the interweaving of older 'collegial' and newer, 'corporate' logics of professionalism within this professional association and the broader project management community. We conclude by developing this model of professionalism, highlighting its necessarily negotiated and hybrid character and discussing its broader relevance for the professionalization of management specialisms.

\section{The Changing Landscape of Management and the Professions}

Research into professions and the process of professionalization tends to be dominated by analyses of a few showcase professions such as law and medicine in Anglo-Saxon contexts (Macdonald, 1995). While early work generally attempts to establish the essential qualities of 'the professions', the key contribution of Johnson (1972) overcame these earlier taxonomic concerns and reorientated this field towards the recognition that professionalism did not refer as much to the intrinsic nature of an occupation but to a 'peculiar type of occupational control' (1972: 45) open in principle to a wide range of occupations.

Traditionally, professionalisation is articulated along two key dimensions; the regulation of production by producers and the regulation of the production of producers (Abel, 1988). The first dimension refers to attempts to control how professional services are produced, distributed and consumed. This involves a process of monopolization, whereby an occupational group seeks to carve out a favourable jurisdictional settlement by advancing claims of exclusive authority over an area of skill and expertise (Murphy, 1988). In its most accomplished form this will lead to a state-sanctioned monopoly over the right to perform certain types of work (e.g. medical prescription) or use certain titles (e.g. Chartered accountant). The second dimension, the production of producers, refers to the attempt to regulate the production of professionals themselves (Abel, 1988), as professions seek to control the supply of professionals by establishing who is qualified to enter the profession as well as the credentials, skills and competences they should possess. This usually relies on a combination of formal examination, testing the mastery of an official body of knowledge, and vocational training designed to socialize the candidate in the norms of a particular community. Occupational closure results from these activities, as professions 'seek to maximise rewards by restricting access to rewards and opportunities to a limited circle of eligibles' (Parkin, 1974: 3). Thus this collegial form of 
professionalism seeks to create a labour market shelter for certain occupations, guaranteeing them a high degree of discretion over their work and empowering them vis-à-vis their customers and potential employers.

However, globalization, deregulation and the rise of large professional services firms in the last few decades (Evetts, 1995; Brock et al, 1999) have challenged this collegial logic in established professions, at the same time that new expert occupations have emerged which defy easy classification. As Fincham notes, these new expert groups are "annoyingly 'different' from each other (...) analytic dimensions are blurred and cut the cards differently for different groups" (2012; 221). Certain new expert occupations have abandoned the template of the collegial professions and have attempted to develop new forms of occupational control, leading to the formulation of a distinct 'knowledge worker' thesis (Blackler, 1995; Reed, 1996). According to proponents, these new symbolic analysts and knowledge brokers are engaged in activities far removed from the remit of the collegial professions and therefore require more entrepreneurial, managerial and informational configurations (Reed, 1996). The most detailed account of these debates is provided by Reed's (1996) typology of expertise. According to this model the 'collegial professions' have been joined by two new occupational categories: 'organizational professions' and 'knowledge workers', which do not rely on traditional occupational closure and collective mobility. Organizational professions, such as personnel or supply chain managers, succeed instead by colonizing key organizational enclaves and positions in the bureaucratic structures they inhabit. They do so by solving technical problems for their employers and adding value through the delivery of efficiency gains (Armstrong, 1985). On the other hand, knowledge workers or entrepreneurial professionals (Muzio et al, 2007), such as management consultants and executive search consultants, eschew professionalisation entirely and instead prioritise marketization, by engaging closely with clients and other stakeholders to continuously develop new products and markets for their expertise (Fincham, 2006). Thus the new forms of expertise compete by identifying and developing new fads and fashions and by tailoring these to the unique circumstances of their clients (Suddaby and Greenwood, 2001). In this context, the assumption in the literature (Reed, 1996; Fincham, 2006; 2012) has increasingly been that for these new occupations, professional closure is neither achievable nor indeed desirable when compared to other occupational strategies.

Recently there have been several calls to reconsider the relationship between professions and organizations (Barley and Tolbert, 1991; Suddaby et al, 2007; Muzio and Kirkpatrick, 2011). In particular Suddaby et al (2007: 357) invite us to 'revisit theories of professionalism, which did not fully anticipate the shift of professional work to the context of large organizations'. Many researchers have taken this up by focusing on contemporary processes of professional formation 
and development, driven by the realization is that 'those professional occupations that have more recently emerged [...] structure themselves so as to accommodate corporate patterns' (Dacin et al., 2002: 49). Accordingly a growing body of work (Kipping et al, 2006; Muzio et al, 2011; Thomas and Thomas, 2014; Paton et al, 2013; Sturdy et al, 2013) have developed the concept of 'corporate professionalism' to characterise new professional projects, such as management consultancy and indeed project management. Whilst clearly an ideal type which has primarily heuristic value, corporate professionalism brings together characteristics of Reed's organizational professionalism and knowledge work categories. Thus, for instance, corporate professions tend to operate organizational as well as individual membership schemes, tie membership structures to corporate careers, actively involve clients in their own governance, and target transnational rather than national jurisdictions (Muzio et al., 2011). Above all, as large organizations are the main users and employers of their expertise, these new professionalization projects are intimately bound to corporate settings, interests and practices (Muzio et al, 2011).

Thus corporate professionalism, by opening up the possibility to some novel patterns of professionalization, provides an alternative to the 'unwilling/unable to professionalize' thesis which has dominated the debate on expert labour for some time. It helps us to understand the case of newer forms of expertise such as management consultancy or project management which are becoming increasingly institutionalized (Muzio et al, 2013) but do not conform with traditional professionalization models. Yet whilst we have some tentative descriptions of what corporate professionalism may entail, we lack an understanding of how this may emerge in practice, as new occupations navigate the path between traditional routes to professionalization and more contemporary marketization strategies. In particular existing research offers little consideration, beyond a generic recognition of the growing influence of corporate stakeholders (Kipping et al, 2006; Kipping, 2011; Muzio et al, 2011), of the internal dynamics through which corporate professionalism is defined and enacted. Thus, little is known of how corporate professionalism draws on and combines the alternative strategies implied by distinct professional logics. This is important if we are to move beyond an understanding of professions as static and abstract categories and recognise them instead as the outcome of active, fluid negotiations between distinct constituents and stakeholders (Burrage and Torstendahl, 1990; Becker et al, 1961).

\section{Methodology}

To address these gaps in our knowledge, we examine the strategies adopted by one professional association, the APM, representing the field of project management in the UK. The APM has been chosen as it appears to have achieved a level of legitimacy through its efforts to professionalise, in 
terms of membership numbers but also, as indicated by the recent award of a Royal Charter, in terms of institutional recognition. By examining how this professionalization project has unfolded, the aim is to reveal the underpinning logics at play in this profession, while at the same time examining the specific forces and processes which have shaped its development.

This research forms part of a larger qualitative study into the dynamics of professionalization within project management at an institutional and individual level. The APM is adopted here as a 'critical case' (Yin, 2003) in the sense that it, as the main representative association for project management in the UK, represents a managerial field which, against expectations, appears to have has some success in its efforts to professionalise. Successful professionalization, here, is clearly a complex issue, as the discussion below underlines, but is best captured by the legitimacy of claims to professional status. Markers of legitimacy for the APM include the significant increase in individual membership (legitimacy among practitioners), increase in corporate membership (legitimacy among employers) and the approval of their application for Royal Charter (state legitimacy). As the study focuses on a single case, the aim of the research is not generalisable findings; rather, the intention is to gain insight into the dynamics affecting the process of professionalisation, taking into account the specific context and history of this occupation.

The study relies on interviews with senior representatives of the APM, alongside the archival analysis of APM documents, publications and online material. A series of semi-structured interviews were conducted in 2007-08 with seven individuals who held, or had held, the most senior positions within the APM between 2000 and 2013. Given the small and high-profile sample, interviewees are referred to simply by number to protect their anonymity. This was supplemented by analysis of documentary materials published by the APM, focusing on the period 2007-2014, including a systematic reading of APM annual reports, relevant articles published in the APM magazine 'Project', APM member blogs, 286 APM presentations on Slideshare, 10 APM webinars and other APM website material and over 1500 contributions to online discussion threads on the APM website. The key aim of this was to contextualise the interviews, and also to compare private and public accounts of the rationale behind the strategies employed over this period.

Semi-structured interviews were used to provide flexible and detailed accounts through the joint construction of meaning in a social encounter, following Holstein and Gubrium's (1995) concept of the 'active interview'. Through active interviewing, our aim was not to extract information or views from a passive subject but to stimulate active narrative production, intentionally provoking interviewees to articulate and reflect upon their position. Interviews followed a standard yet broad protocol, lasted between 30 minutes and 2 hours and were recorded, transcribed, anonymised and entered into NVivo for analysis. The outcome of each interview was a rich and grounded account 
which represents an articulation of the 'world-view' of informed and influential subjects in this particular field, illuminating the formation and implementation of strategy here.

The research questions for these interviews were derived from literature on the sociology of the professions, focusing on five themes which are particularly prominent across this literature: the philosophy underpinning the professionalisation strategy (e.g. Freidson, 2001), the historical evolution of the association and the field (e.g. Larson, 1977), the jurisdiction of the association (e.g. Abbott, 1988), the structure of credentials (e.g. MacDonald, 1995; Freidson, 2001), and the association's key stakeholders (Burrage and Torstendahl, 1990). Two coders jointly analysed the transcripts through an open coding strategy, which produced 50 codes. Through axial coding, categories were created to group coded data; through this process, it was found that 40 codes could be related to four core categories: (1) governance, (2) stakeholders/relationships, (3) occupational closure and (4) jurisdiction; the remaining ten codes were collated within a broader category covering history, philosophy and professional status. These categories were examined holistically by a third researcher for discursive coherence and to establish a common lexicon for interpretation and analysis. Then, through a process of selective coding, the four categories were built into an emergent narrative (Strauss and Corbin, 1998), forming the structure for the analysis section below. Issues related to (1) governance are dealt with alongside history, philosophy and professional status in the introductory section below. The remaining three sections address, in turn, (2) stakeholders/relationships, (3) occupational closure and (4) jurisdiction.

\section{The Professionalisation of Project Management in the UK}

Before looking in detail at key aspects of the professionalization strategies and logics within the APM, it is necessary to introduce project management as a function, and to provide some context on its evolution, both globally and within the UK itself, in order to locate some of the broader occupational dynamics impacting on the profession. Project management combines managerial and technical responsibilities, drawing on a proprietary body of knowledge and associated practitioner methodologies to plan, monitor and coordinate projects in a range of sectors (Hodgson, 2002). Project managers are typically employed within large organisations, where they help to realise the objectives of their employers, with a minority serving such organisations from independent and relatively small consultancies (Morris, 1997; Zwerman and Thomas, 2001). Project management represents a weakly institutionalised occupational field (Greenwood et al, 2002), in that there is no regulation of the production of producers in terms of occupational barriers to entry or no legal or other institutionalised restrictions on the right to practice as a 'project manager'. 
Globally, project management tends to be represented by national associations, which vary widely in size, influence and respectability. The dominant professional association for project managers in the UK, the APM, was created in 1972 by a network of practitioners interested in a particular PM methodology. Over the last forty years, the activities of the APM have broadened to cover many of the functions of collegial professional associations, including the certification of knowledge and skills, production of an official body of knowledge (APM, 2012) accompanied by an ethical code, and representation as far as possible of the disparate elements of an occupation still dominated by engineering, construction and IS/IT. The APM is currently the second-largest professional association for PM in the world, and the largest outside of the US where the American Project Management Institute (PMI) dominates (Hodgson, 2008; Hodgson and Muzio, 2011). With the exception of the $\mathrm{PMI}$, most national associations are members of the International Project Management Association (IPMA), a federal umbrella organisation linking 55 national associations for project management. The APM is by some distance the largest IPMA member, making up over $40 \%$ of the IPMA's 50,000 members worldwide.

Through the 1970s/80s, individual membership of the APM expanded slowly and by the early 1990s membership remained at a modest 2000 (see Figure 1). The decision was taken in 1991 to publish the APM 'Body of Knowledge' (BOK), presented as 'the ontology of the profession; the set of words, relationships and meanings that describe the philosophy of project management' (Morris et al, 2000: 156), and also to introduce a professional examination based on the BOK, covering key PM skills such as planning, budgeting and risk management. Several in the APM leadership identify these actions as triggering a sharp increase in APM membership from 1996 onwards, as many practicing project managers were attracted by the prospect of formally accrediting their expertise. Although slowing down for a period in the late 1990s, the association has continued to expand its membership at a very healthy rate (see Figure 1), building to its present membership of over 21,000 individuals (APM, 2014a), with 90,000 qualified APM practitioners to date and a $f 7$ million turnover (APM, 2014b).

INSERT FIGURE 1 HERE

While growth in individual membership can be pointed to as one indicator of the APM's success, there are other indicators of its growing influence. Recent presentations at the APM's Annual General Meetings have emphasised the wider impact of the APM beyond direct membership, pointing to 28,000 Linkedln followers of the APM, and 3.25 million hits per annum to the APM 
website (APM, 2013b). In addition, there has been a substantial increase in corporate membership in the last decade, the APM now boasting over 570 member companies (APM 2013b). The APM have three accreditation schemes; Corporate Accreditation which assesses and approves an organisations professional development scheme for project management staff; Training and Development accreditation where independent training providers have their course materials assessed against the APM standards; and Academic accreditation where universities seek to have courses and modules are aligned to the APM Body of Knowledge. To date, 50 major public and private sector organisations have acquired formal APM accreditation for their project management development programmes, including BAe systems, United Utilities, Shell and the UK Ministry of Defence, and over 90 universities and private companies have received APM Academic or Training and Development accreditation (APM, 2014). With the increasing uptake of these schemes some industries are adopting the APM as the de facto quality standard for project management practice with companies in, for example, the oil and gas, defence and construction sectors now finding it necessary to possess APM approval of system and staff to allow entry to the supply chain.

In addition to its success within industry, the APM have also applied for status as a Chartered professional body. A Royal Charter is highly significant here as it represents the highest form of UK state recognition for an occupation and would symbolically place project management on the same level as established professions such as accountancy and engineering. In July 2013, the APM was informed that, the Privy Council committee had unanimously recommended that a Royal Charter should be granted. Although delayed by an unsuccessful appeal from the UK chapter of the USbased Project Management Institute the APM, in gaining Chartered status, should soon join a very select group of just six Chartered management specialisms ${ }^{1}$.

Yet, throughout this period of substantial expansion and increasing legitimacy in the eyes of practitioners, employers and the State, differing opinions existed within the APM around how professionalism was understood and how it should be accomplished. This internal debate is important as it explains how its journey to professionalism was to assume a distinctive character, combining an attachment to the traditions of collegial professionalism with the development of some new and decisively innovative features. Not surprisingly, the APM was inevitably influenced by the existing recipes and models provided by the traditional/collegial professions, which acted as a

\footnotetext{
${ }^{1}$ The vast majority of the 115 Royal Charters awarded in the last thirty years have gone to professional bodies for technical occupations (medical, engineering or accounting) (Privy Council, 2014). Only 6 of these 115 relate to what might be called management sub-disciplines; the Chartered Institute of Marketing (1989), the Chartered Institute of Purchasing and Supply (1992), Chartered Institute of Personnel and Development (2000), Chartered Management Institute (2002), The Chartered Institute of Public Relations (2005) and The Worshipful Company of Management Consultants (2007),
} 
template and reference point for its own occupational ambitions. This influence was apparent as many project managers qualified or trained in other professional fields, such as engineering, and therefore had exposure to the practices, discourses and structures of more collegial and established models of professionalism.

The best example of this influence is the pursuit of the Royal Charter itself, which traditionally defined collegial professions in the UK and which the APM set out as its own core strategic objective in 2007. The following quotes capture both the strategic importance that APM places on the Royal Charter and the impact that this objective has had on its professionalization strategy:

We would then be the body for project managers in the UK and nobody could argue with that. We'd be up there as an equivalent professional body with all the others. (APM2)

All the things that we were doing - enhancing and building the reputation, the strength of the organisation and its finances - would contribute somehow or other to an application for becoming Chartered. (APM3)

The conditions associated with a Royal Charter, requiring that an association prove pre-eminence in the field and its contribution to the 'public good' (Privy Council, 2014), had some important consequences. In particular, as interviewees attested, it informed the APM's 'Delivering the Future' campaign (APM, 2011), whereby the APM has recently begun to emphasize its public interest credentials, positioning itself as a trustee of socially important skills which are fundamental to individual and societal well-being (Brint, 1994). This emerges clearly from the following quote with its references to public good, society and even civilisation.

I think it's reflected in the strapline that they've been using about delivering the future.

The future has to be delivered, we are in constant change. (...). But that change is very important and it is generally for the public good in the sense of developing civilisation. It wasn't like that ten or 15 years ago (...) when we say we'd like to do it for the public good, the public now generally says 'yes please', as opposed to 'who the hell are you?' (APM4)

More recently the APM's "2020 Strategy", sets out an explicit 'public good' argument, identifying 'society' as one of the beneficiaries of its professionalization efforts; "With scarce resources and infinite opportunity, society demands greater effectiveness, transparency, accountability and a zero tolerance of failure" (APM, 2013a). The deployment of public interest arguments by the APM speaks to a collegial model of professionalism and indicates a departure from the usual rhetoric of new 
forms of expertise which have tended to emphasize their problem-solving skills and ability to add value in a narrow and technical sense (Brint, 1994).

The pursuit of the Royal Charter, as an aspect of the APM's professionalization strategy, is thus both a driver and an intended outcome, and on the surface appears to mark a commitment to collegial models of professionalism and professionalization. However, our interviews reveal the articulation of an alternative and rather different understanding of professionalism within project management. This view implicitly rejects the pomp and symbolism associated with collegial British professions, described by one interviewee as "limestone and gold chains and crests with funny animals", and envisages a kind of modern 'greenfield' professionalism. Another interviewee captured succinctly the radical nature of the thinking within sections of the APM:

If you really sort of sat down with a blank sheet of paper and said what would modern body be like and what would it do and how would you engage the majority of the members? You would probably come up with something quite different from what any traditional professional body does. (APM2)

Importantly this scepticism questions the pursuit of a Royal Charter, as it embodies the collegial understanding of professionalism. This is articulated by the following respondent who questions the value of a Royal Charter in what is an increasingly transnational jurisdiction.

There's nobody outside the UK would even know what Chartered status meant. And if they asked you what it meant and you said 'this means the Queen has signed a piece of paper, which says we're the professional body', they would think you were pulling their leg! (APM2)

As shall be discussed below, this tension between different logics of professionalism pervades the recent history of the APM. The tensions between the collegial, organizational and entrepreneurial in turn explain the complex character of this particular model of professionalism, where old and new coexist. In the sections below, three aspects will be examined in turn and compared to collegial models of professionalism, noting in each case the competing logics at play.

\section{Stakeholder Focus}

The most striking aspect of the APM's professional model relates to the renegotiated relationship between the association and its three key stakeholders; the individual members, corporations as employers or clients of project management services, and the state in the form of various UK government agencies. Whilst historically the APM had, much like collegial professions, focused on qualifying and regulating the individual practitioner, the recent priority has been to engage much 
more closely with major corporations, and to invite them to influence policy through the formation of a Corporate Members Advisory Group in 2007, relaunched in 2013 as the Corporate Members' Leadership Group. The rationale for this is articulated clearly below;

APM would want to have corporate members as well as individual members because it gives us a chance to expand our sphere of influence, into not just talking to individuals but talking to some quite powerful 'structurers'. (APM3)

Of course, the patronage of APM corporate members also helps in recruiting individual members, who are likely to be encouraged in varying degrees by their employer or clients to become accredited, with some employers paying membership fees for their employees. To further encourage this corporate patronage the APM introduced a distinct corporate membership scheme, which has grown rapidly in the last decade from 150 to over 550 members. Further this link to corporations has recently been strengthened by the decision of the APM to directly accredit the professional development schemes of corporate employers; at the time of writing, 20 companies held APM Corporate Accreditation, including Shell, Fujitsu, Siemens and Rolls-Royce. Corporations thus gain accreditation by providing evidence that their schemes are aligned with the APM's ' 5 Dimensions of Professionalism', itself built around the APM body of knowledge. As a professionalization tactic this is innovative, as it empowers corporate members to qualify and certify individual practitioners, a task which had traditionally been the exclusive remit of professional associations.

Further evidence of the increasing role of the corporation is found as various interviewees testified to the powerful indirect influence of corporate members on APM policy. For instance, several argued that pursuit of the Royal Charter was pushed most strongly by corporate members, who even participated in funding the costs of this initiative;

A number of (the corporate members) are prepared to sponsor the Chartered status initiative by actually contributing money towards the cost of doing it. Quite significant funds actually... So we don't look a gift horse in the mouth! (APM5)

The benefits of a higher status for project management in the eyes of its corporate members are made more explicit in the following quote, which connects the professionalization of project management to the internal dynamics of the corporation;

The view began to become more strident from corporate members and particularly from people like BAe and Rolls Royce, that they needed 'Chartered' (status) ... and therefore they expected APM to be moving down that road... Some of the corporates are looking to APM to provide them with a means of leapfrogging their project 
managers over their engineering managers, in terms of status and influence... That's one of the drivers for seeking Chartered status because that puts them at least on an equal footing with a chartered engineer. (APM3)

In this way, a Royal Charter becomes a resource that employers and employees can deploy to enhance their control over major projects by enhancing the professional status of project management vis-à-vis other technical professions.

While relationships with corporations represent a major departure for more collegial models of professionalism, corporate membership is not implemented fully at the expense of the individual as corporate membership is subject to a degree of attenuation. Corporate members do not currently hold formal positions on the APM's board, and as one interviewee explains, "corporates do not have a say in any votes or issues that are put forward" (APM4). The relationship between stakeholders can therefore be seen to be a mixture of those characteristics common to collegial professions with some distinctively new features which are designed to recognize and accommodate the decidedly corporate setting of project management.

\section{Occupational Closure}

Occupational closure regimes and the regulation of the production of producers within project management reflect a more complex interweaving of collegial and corporate professionalization strategies. The APM's efforts to develop a body of knowledge, and its emphasis on testing the mastery of this body of knowledge to adjudge professional proficiency, reflects an orientation towardscollegial professionalization, although unlike collegial professions, this has been largely effected without significant engagement with universities. The success of the APM in creating the APM Body of Knowledge (APM BOK) sets it apart from several other management occupations which have embarked in their own professionalization journeys but have struggled to bound and codify their knowledge domain (Fincham, 2006). The implementation of the APMP, a stand-alone test of a candidate's mastery of the BOK, was the initial mechanism to qualify for practice, reflecting very collegial forms of occupational closure; interviewees described this as the initiative which significantly accelerated the growth in individual membership in the APM. However, despite this popularity, this did not lead to tight occupational closure, in the sense of a widely-recognised and routinely-expected professional qualification found in collegial professions such as medicine.

More recently, in project management, accreditation has shifted from input- to output-based measures, with a greater emphasis on practice, experience and, importantly, value delivered to client or employer. The publication in 2008 of the APM Competence Framework, which differentiates technical, behavioural and contextual competences, introduces a shift from the APMP 
single point of entry to a 4-tier hierarchy of accreditation, with increasing emphasis on enacted competences assessed through evaluations of performance (Hodgson and Muzio, 2011; APM, 2013a).

Some interviewees suggested that the development of a hierarchy of accreditation and moves to create products such as competence frameworks were again primarily driven by the needs of corporate members;

What I've found with corporate members mostly is that they actually seem to like the certification. What everybody's looking for (is) somebody that can say if Joe Bloggs has got a certificate, the likelihood of our projects being more successfully managed is improved. (APM6)

The APM BOK and competence framework combined with the 4-level accreditation structure provide a valuable resource for corporations seeking to create internal labour markets supported by their own competency frameworks for training and/or assessment. This tactic of pursuing occupational closure through joint APM/corporate accreditation is further advanced where corporations, as previously discussed, go on to seek explicit APM Accreditation for their development programmes. Success here is built up a long-term process of convincing employers that the APM can help them take greater control of the training, development and career structure of project managers, by persuading them that;

They needed to think about project management training and project management staff but from a corporate angle rather than an individual angle. (APM7)

Thus, a complex picture of professional enclosure emerges here; we have clear evidence of collegial professionalism through the establishment and testing of an abstract body of knowledge, alongside more innovative developments such as competence-based closure through the accreditation of experience as valued by clients/employers, and the embedding of training/accreditation within corporate career structures. These approaches exemplify the complex interweaving of strategies built upon collegial and corporate professional logics.

\section{Jurisdiction}

Historically, the reliance of professions on the patronage of the state has rendered most professions nationally-bounded, and the APM certainly retains a strong national identity, reflected in the fact that the APM's individual members are overwhelmingly based in the UK (and certain Commonwealth countries) (APM, 2014). The domestic boundaries of the APM are reinforced by their membership of the International Project Management Association (IPMA), an umbrella group 
comprised of 56 national project management associations. While the IPMA provides a forum for the coordination of activity between national PM associations, it also implicitly discourages international expansionism on the part of any member association, adopting the 'one association one nation' stance.

The sustainability of this position on the part of the APM and the IPMA in an era of globalisation is open to question, as project managers move internationally within and between multinational firms, and routinely coordinate cross-border activity. Despite their current limited international reach, the APM appears increasingly aware of the importance of the global, rather than domestic, scope of their occupation; one interviewee thus describes PM as 'the first international profession' (APM2). Here again the influence of multi-national corporations on the APM's model of professionalism is key, as corporations demand consistency in how project managers practice as they engage in global projects, maintain infrastructure in many countries and transfer staff across national boundaries. As one interviewee predicts;

We do get organisations that operate in many European countries and probably do want at some point to come to a common platform of capability and process. (APM4)

There are thus pressures on the APM to move towards a market-oriented model of professionalism based upon the possibility of the worldwide promotion and marketing of the APM brand and associated qualifications, freed from any reliance upon a national base. Developments such as the creation of an ISO standard for project management (ISO21500, 2012) reflect demands for global consistency in terminology and practice, and also highlight the need for not only domestic but international reach to influence such developments. A professional association restricted by national boundaries therefore appears as both a quaint anachronism and a less attractive business partner.

Again, we find a complex pattern made up of old and new professionalization strategies; to a large degree the APM maintains a national focus, with any international ambitions are bounded by and channelled through the IPMA. In light of these global ambitions, as illustrated above, there are some misgivings among APM senior representatives over the priority given to acquiring a Royal Charter, whose credibility in the UK may have limited impact internationally. As one argued;

Why should we just worry about a UK-only issue when in fact what we were trying to do was promote project management to our membership - who work all over the world? (APM4)

By contrast, credibility based on corporate support drawn from multinational corporations is seen to translate readily beyond national boundaries, and ironically, the price for such corporate support may be the pursuit of a Royal Charter. 


\section{Project Management in the UK as a Hybrid Profession}

Our analysis above seeks to clarify the essential duality within contemporary professional projects (Kipping et al, 2006; Muzio et al, 2011; Thomas and Thomas, 2014) as exemplified by the case of project management. Professionalisation here is pursued through a strategy composed of various tactics, each reflecting particular logics. These logics are understood as a socially-constructed value and meaning system which serves to "provide taken-for-granted conceptions of what goals are appropriate and what means are legitimate to achieve these goals" (Pache and Santos, 2013: 973). Given that professionalism has constantly evolved as 'the product of a dialectical relationship with its environment' (Hanlon 1999: 3), it is no surprise that the APM's strategy is by necessity hybrid, formed in negotiation with the changing demands of its fluid environment and heterogeneous stakeholders. Our analysis reveals two distinct professional logics at work within the APM, as indicated in Table 1. These provide different visions and normative prescriptions for the future of project management.

\section{INSERT TABLE 1 ABOUT HERE}

We characterise the first logic as one of 'collegial professionalism', given its direct reference to established forms of professionalism. Indeed a number of our respondents explicitly state the intention to reach 'equal footing with Chartered engineers'. Thus, there is continuity between their vision for project management and established patterns of professionalization, centred in particular on the model of Chartered engineering. We identify a competing logic, which following the literature (Kipping et al, 2006; Muzio et al, 2011; Paton et al, 2013; Thomas and Thomas, 2014) we define as one of 'corporate professionalism'. This is still emergent and not as clearly articulated as the previous one but it signals aspirations for innovation and departure from established models of professionalization. Thus our respondents convey a sense of renewal when they refer to starting afresh 'with a blank sheet of paper' or advocate the need for a new model of 'greenfield professionalism' fit for the $21^{\text {st }}$ century. Moreover, the renewal is in many ways presented as in opposition to the symbols and discourses of collegial professionalism such as the limestone and gold chains and crests with funny animals' or the endorsement by the Queen. In opposition to this the corporate logic suggests a more dynamic and internationally-oriented approach, whereby professions are expected to legitimize themselves by demonstrating their ability to add value by solving technical problems for their employers (Brint, 1994). 
Importantly, these logics inspire a range of distinctive strategies, which have shaped the development of this particular profession. Thus on one hand, the 'collegial' logic supports strategies associated with established forms of professionalism. Hence APM in its attempt to reach equivalence with the 'old' professions is adopting many of their original features: it has successfully developed a comprehensive and systematic body of knowledge (the APM BOK), it has devised a closure regime centred on technical knowledge and formal examinations, and has obtained the ultimate professional accolade in the form of a Royal Charter. Yet, on the other hand, the vision for an alternative future embodied by the logic of 'corporate professionalism' inspires a series of new and innovative strategies. These include: the development of competence-based qualification processes which test real skills often in organizational settings, the introduction of corporate membership schemes and the development of multi-tier membership propositions, tied to different qualifications and linked to organizational career structures. Importantly, these new innovations have a distinctive corporate dimension as they recognize the predominantly organizational context and orientation of project management work. Accordingly, the APM has tried to devise new systems to reflect, engage with and take on board corporate interests and practices.

Beyond merely identifying a duality, it is important to illustrate how this new profession seeks to reconcile this duality, pursuing aspects of both collegial and corporate professionalism in parallel, often synthesising different logics so that "old and new coexist and co-penetrate each other" (Muzio et al 2011: 459). The outcome of this process of synthesis is a hybrid model of professionalism (Kurunmäki, 2004; Noordegraaf, 2007; Thomas and Hewitt, 2011), which combines elements from apparently contradictory logics (Reay and Hinings, 2009) in an attempt to establish or maintain legitimacy with multiple stakeholders in an increasingly complex social, political and organisational environment. Critically, hybrids necessitate the management of tensions between distinct logics and offer the promise of success through achieving complementarity out of contradiction (Fischer and Ferlie, 2013). So, for example, Malsch and Gendron (2013) in their analysis of the development of large accountancy firms, show how such organizations have to reconcile a process of commercial expansionism with a defence of traditional professional practices, as they step out of the accountancy field to expand into new areas such as management consultancy whilst at the same time protecting and leveraging their traditional auditing monopolies In this context 'neither the commercial nor professional logic can afford to supplant the other. The two logics must coexist in a precarious state' (Malsch and Gendron, 2013: 889).

Similarly, in project management, APM seeks to claim the legitimacy of traditional professional practices, discourses and accolades whilst at the same time stressing its modern, innovative and cosmopolitan credentials. Thus, this is not a simple story of shifting logics, where a newer logic 
(corporate professionalism) becomes dominant and displaces a more established, traditional one (Greenwood et al, 2002). Rather, this case indicates how key actors selectively and opportunistically draw on and recombine elements of different logics to pursue desired outcomes. So, for instance, the APM seeks governmental approval through a Royal Charter, and to do so must promulgate public interest arguments, but it does so in part at the behest of corporate members to whom it markets itself by stressing its ability to add commercial value. Similarly, new forms of competencebased closure are overlaid on more collegial forms of accreditation whilst corporate membership schemes are used to boost individual membership as corporate members are expected to encourage their individual project managers to join the APM. Importantly, rather than presenting actors as cultural dopes responding to the changing prescriptions of their institutional environment (Suddaby, 2010), our story shows their active role as skilled agents stitching together competing logics in the attempt to develop new occupational structures (Fligstein, 1997; McPherson and Sauder, 2013), as evidenced in the accounts above. Thus, the same groups or individuals selectively draw on distinct if not contrasting logics, pragmatically recombining their different motivations and prescriptions as part of their drive towards professionalization.

\section{Conclusion}

Despite claims that professionalism is no longer viable for management specialisms, the case of project management provides evidence of the successful professionalisation of a management specialism in the UK, measured in terms of legitimacy among practitioners, employers and the State. The approach to professionalisation adopted by the APM, however, defies easy classification. Our analysis points to the emergence of a hybrid professionalisation strategy, driven by the need to combine distinct logics and achieve and maintain legitimacy with different stakeholders.

Our contribution is four fold. First, we respond to the call to revisit theories of professionalism, (Suddaby et al, 2007) by providing an example of a recent successful instance of 'corporate professionalism' (Muzio et al, 2011) whereby a new profession develops with reference to corporate interests and practices. Second, we clarify the duality of corporate professionalism. In particular, within this particular occupational context, two logics of professionalism coexist in a hybrid form, as organizational and entrepreneurial strategies are integrated with more traditional/collegial ones. Our third contribution is to illustrate how this new profession seeks to reconcile this duality, pursuing aspects of both traditional/collegial and new/corporate professionalism in parallel, often synthesising different logics to overcome apparent contradictions between logics. The outcome of this process of synthesis is a hybrid model of professionalism (Kurunmäki, 2004; Noordegraaf, 2007; Thomas and Hewitt, 2011). Our final contribution is to describe this hybridisation process, detailing 
how actors selectively and opportunistically draw on and recombine elements of different logics to pursue professionalization. In doing so, the paper contributes in a distinctive way to a growing body of work looking at institutional logics and their interaction (Reay and Hinings, 2009; Pache and Santos, 2013; McPherson and Saunder, 2013; Kodeih and Greenwood, 2014).

As an exploratory case study of a single profession, this study raises a number of avenues for future research. Firstly it would be important to look in detail at other examples of new professionalization projects, such as management consultancy or supply management, to look for similarities and departure points with the strategies successfully deployed by project management. Such comparative work will help to better understand both the characteristics of this corporate professionalism and the conditions under which it can prosper. Secondly, as professions are geographically-embedded institutions (Faulconbridge and Muzio, 2007) more cross-national research is required to answer questions such as how are project management and other corporate professions developing in continental societies characterised by high levels of governmental involvement in professionalization projects? Thirdly, as project management is characterised by multiple professional associations such as America's PMI, this would provide a unique opportunity to study the staging of competing professionalization projects within an occupational remit. Do these situations lead to arbitrage opportunities where members play off different associations against each for better terms and conditions? Do they trigger a race to the bottom where professional associations downplay their regulatory role? Finally, more research is required to understand the consequences of corporate professionalism for practitioners and consumers alike. Does it help to raise quality and ethical standards in a world where traditional professionalism is increasingly de-legitimized? We hope these and other questions can be addressed in a rich programme of further research.

\section{References}

Abel, R.L. (1988) The Legal Profession in England and Wales, London, Blackwell.

Ackroyd, S. (1996) 'Organization Contra Organizations: Professions and organizational change in the United Kingdom', Organization Studies, 17, pp. 599-621.

Ackroyd, S. and D. Muzio (2007) 'The Reconstructed Professional Firm: Explaining change in English legal practices', Organization Studies, 28, pp. 729-747.

Armstrong, P. (1985) 'Changing Management Control Strategies - the Role of Competition between Accountancy and Other Organizational Professions', Accounting Organizations and Society, 10, pp. 129-148. 
Association for Project Management (2011) A History of the Association for Project Management, http://www.apm.org.uk/History, accessed 14/7/2014.

Association for Project Management (2012) Body of Knowledge, http://www.knowledge.apm.org.uk/bok-splash, accessed on 14/7/2014.

Association for Project Management (2013a) APM Strategy 2020 http://www.apm.org.uk/2020, accessed 12/6/2014.

Association for Project Management (2013b) Overview of APM Vision and Strategy, www.slideshare.net/assocpm/a-world-in-which-all-projects-succeed, accessed 8/10/2013.

Association for Project Management (2014a) APM Website http://www.apm.org.uk, accessed $24 / 5 / 2014$.

Association for Project Management (2014b) APM Developing P3M Professionalism London 9th July 2014, http://www.slideshare.net/assocpm/apm-london-090714 _ accessed 14/7/2014.

Barley, S.R. and P.S. Tolbert (1991). 'Introduction: At the intersection of organizations and occupations'. In P. S. Tolbert \& S. R. Barley (Eds.), Research in the sociology of organizations: Vol. 8 (pp. 1-13). Greenwich, CT: JAI Press

Becker, H., B. Geer, E. Hughes, and A. Strauss (1961). Boys in white: Student culture in medical school, Chicago, University of Chicago Press.

Blackler, F. (1995) 'Knowledge, Knowledge Work and Organizations: An Overview and Interpretation', Organization Studies, 16, pp. 1021-1046.

Brint, S.G. (1994) In an Age of Experts, Princeton, Princeton University Press.

Broadbent, J., M. Dietrich and J. Roberts (eds.) (1997) The End of the Professions? The Restructuring of Professional Work, London, Routledge.

Brock, D, M. Powell and C.R. Hinings (1999) Restructuring the Professional Organization: Accounting, Healthcare and Law, London, Routledge.

Burrage, M. and R. Torstendahl (eds.) (1990) The Professions in Theory and History, London, Routledge.

Edwards, L. (2014) 'Discourse, credentialism and occupational closure in the communications industries: The case of public relations in the UK', European Journal of Communication 29, pp. 319-334.

Enright, M. (2006) 'The marketing profession: evolution and future', Journal of Public Affairs 6 pp. 
Evetts, J. (1995) 'International Professional Associations - the New Context for Professional Projects', Work, Employment and Society, 9, pp. 763-772.

Faulconbridge J.R. and D. Muzio (2007) 'Reinserting the professional into the study of professional service firms: the case of law', Global Networks, 7, pp. 249-270.

Fincham, R. (2006) 'Knowledge Work as Occupational Strategy: comparing IT and management consulting', New Technology, Work and Employment, 21, pp. 16-28.

Fincham, R. (2012) 'Expert labour as a differentiated category: power, knowledge and organisation', New Technology, Work and Employment, 27, pp. 208-223.

Fischer, M.D. and E. Ferlie (2013) 'Resisting hybridisation between modes of clinical risk management: Contradiction, contest, and the production of intractable conflict', Accounting, Organizations and Society, 38, pp. 30-49.

Fligstein, N. (1997) 'Social Skill and Institutional Theory', American Behavioral Scientist, 40, pp. 397405.

Freidson, E. (2001) Professionalism: The third logic, Chicago, University of Chicago Press.

Greenwood, R., R. Suddaby and C.R. Hinings (2002) 'Theorizing change: the role of professional associations in the transformation of institutionalized fields', Academy of Management Journal, 45, pp. 58-80.

Hanlon, G (1999) Lawyers, the State and the Market: Professionalism revisited. Basingstoke, Macmillan.

Hanlon, G. (1998) 'Professionalism as Enterprise: Service class politics and the redefinition of professionalism', Sociology, 32, pp. 43-63.

Hodgson, D.E. (2002) 'Disciplining the Professional: The case of project management', Journal of Management Studies, 39, pp. 803-821.

Hodgson, D.E. (2008) 'The New Professionals: Professionalization and the Struggle for Occupational Control in the Field of Project Management', in Muzio, D., S. Ackroyd and J.F. Chanlat (eds) New Directions in the Study of Expert Labour, London, Palgrave.

Hodgson, D.E. and D. Muzio (2011) 'Prospects for Professionalism in Project Management', in Morris, P.W.G., J. Pinto and J. Söderlund, The Oxford Handbook on Project Management, Oxford, Oxford University Press.

Holstein, J.A. and J.F. Gubrium (1995) The Active Interview. Thousand Oaks, CA, Sage. 
International Standards Organisation (2012) ISO21500:2112 Guidance on Project Management, http://www.iso.org/iso/home accessed on 11/11/2013.

Johnson, T.J. (1972) Professions and Power. London, Macmillan.

Khurana, R. and N. Nohria (2008) 'It's Time to Make Management a True Profession', Harvard Business Review, 86, pp. 70-77.

Kipping, M. (2011) 'Hollow from the start? Image professionalism in management consulting', Current Sociology, 59, pp. 530-550.

Kipping, M., I. Kirkpatrick and D. Muzio (2006) 'Overly controlled or out of control? Management consultants and the new corporate professionalism', in Craig, J (ed) Production Values: Futures for Professionalism, London, Demos.

Kodeih, F. and R. Greenwood (2014) 'Responding to Institutional Complexity: The Role of Identity', Organization Studies, 35, pp. 7-39.

Krause, E.A. (1996) The Death of the Guilds: Professions, states and the advance of capitalism: 1930 to the present, Connecticut, Yale University Press.

Kurunmäki, L. (2004) 'A hybrid profession - the acquisition of management accounting expertise by medical professionals', Accounting, Organizations and Society, 29, pp. 327-347.

Macdonald, K.M. (1995) The Sociology of the Professions, London, Sage.

Malsch, B., and Gendron, Y. 2013. Re-theorizing change: Institutional experimentation and the struggle for domination in the field of public accounting. Journal of Management Studies, 5, pp. 871-899.

McLeod, C., S. O'Donohoe and B. Townley (2011) 'Pot Noodles, Placements and Peer Regard: Creative Career Trajectories and Communities of Practice in the British Advertising Industry', British Journal of Management, 22, pp. 114-131.

McPherson, C. M. and M. Sauder (2013). 'Logics in Action: Managing Institutional Complexity in a Drug Court', Administrative Science Quarterly, 58, pp. 165-196.

Miller, P., L. Kurunmäki and T. O'Leary (2008) 'Accounting, hybrids and the management of risk', Accounting, Organizations and Society, 33, pp. 942-967.

Morris, P.W.G. (1997) The Management of Projects. London, Thomas Telford. 
Morris, P.W.G., M.B. Patel and S.H. Wearne (2000) 'Research into Revising the APM Project Management Body of Knowledge', International Journal of Project Management, 18, pp. 155-164.

Murphy, R. (1988) Social Closure: The theory of monopolization and exclusion. Oxford, Clarendon Press.

Muzio, D., D.E. Hodgson, J. Faulconbridge, J. Beaverstock and S. Hall (2011) 'Towards Corporate Professionalization: The case of project management, management consultancy and executive search', Current Sociology, 59, pp. 443-464.

Muzio, D., S. Ackroyd, and J.F. Chanlat (eds.) (2007) Redirections in the Study of Expert Labour. Basingstoke, Palgrave.

Noordegraaf, M. (2007) 'From "Pure" to "Hybrid" Professionalism: Present-Day Professionalism in Ambiguous Public Domains', Administration \& Society, 39, pp. 761-785.

Noordegraaf, M., M. Van Der Steen and M. Van Twist (2014) 'Fragmented or Connective Professionalism? Strategies for professionalizing the work of strategists and other (organizational) professionals', Public Administration, 92, pp. 21-38.

Pache, A.C. and F. Santos (2013) 'Inside the Hybrid Organization: Selective Coupling as a Response to Competing Institutional Logics', Academy of Management Journal, 56, pp. 972-1001.

Parkin, F. (1974) The Social Analysis of Class Structure. London, Tavistock.

Paton, S., D.E. Hodgson and D. Muzio (2013) 'The Price of Corporate Professionalization: Analysing the corporate capture of professions in the UK and consequences for expert labour', New Technology, Work and Employment, 28, pp. 227-240.

Privy Council (2014) Chartered Bodies http://privycouncil.independent.gov.uk/royalcharters/chartered-bodies/ accessed on 1/7/14.

Reay, T. and C.R. Hinings. (2009) 'Managing the Rivalry of Competing Institutional Logics', Organization Studies, 30, pp. 629-652.

Reed, M. (1996) 'Expert power and control in late modernity: an empirical review and theoretical synthesis', Organisation Studies, 17, pp. 573-597.

Reed, M. and P. Anthony (1992) 'Professionalizing Management and Managing Professionalization British Management in the 1980s', Journal of Management Studies, 29, pp. 591-613.

Strauss, A.L. and J.M. Corbin (1998) Basics of Qualitative Research: Grounded theory procedures and techniques. London, Sage. 
Sturdy, A. (2011) 'Consultancy's Consequences? A Critical Assessment of Management Consultancy's Impact on Management', British Journal of Management, 22, pp. 517-530.

Sturdy, A., N. Wylie and C. Wright (2013) 'Management Consultancy and Organizational Uncertainty The Case of Internal Consultancy', International Studies of Management and Organization 43, pp. 58-73.

Suddaby, R and R. Greenwood (2001) 'Colonizing knowledge: Commodification as a dynamic of jurisdictional expansion in professional service firms', Human Relations, 54, pp. 933-953.

Suddaby, R. (2010) 'Challenges for Institutional Theory', Journal of Management Inquiry, 19, pp. 1420.

Suddaby, R., D. Cooper and R. Greenwood (2007) 'Transnational regulation of professional services: Governance dynamics of field level organizational change'. Accounting, Organizations and Society, 32, 333-362.

Thomas, P and J. Hewitt (2011) 'Managerial Organization and Professional Autonomy: A DiscourseBased Conceptualization', Organization Studies, 32, pp. 1373-7393.

Thomas, R. and H. Thomas (2014) 'Hollow from the start? Professional associations and the professionalization of tourism', The Service Industries Journal, 34, pp. 38-55.

Veldman, J. (2013) 'Politics of the Corporation', British Journal of Management, 24: pS18-S30.

Walker, D.S and Child, J. (1979) 'The Development of Professionalism as an Issue in British Marketing', European Journal of Marketing, 13, pp. 27-54

Whittington, R., L. Cailluet and B. Yakis-Douglas (2011) 'Opening Strategy: Evolution of a Precarious Profession', British Journal of Management, 22, pp. 531-544.

Wright, C. (2008) 'Reinventing Human Resource Management: Business Partners, Internal Consultants and the Limits to Professionalization', Human Relations, 61, pp. 1063-1086.

Yin, R.K. (2003) Case Study Research: Design and methods London, Sage.

Zwerman, B. and J. Thomas (2001) 'Barriers on the Road to Professionalization', PM Network, 15, pp. $50-62$. 
Figure 1: APM Membership Growth 1972-2014 (Source: APM, 2011; 2014a)

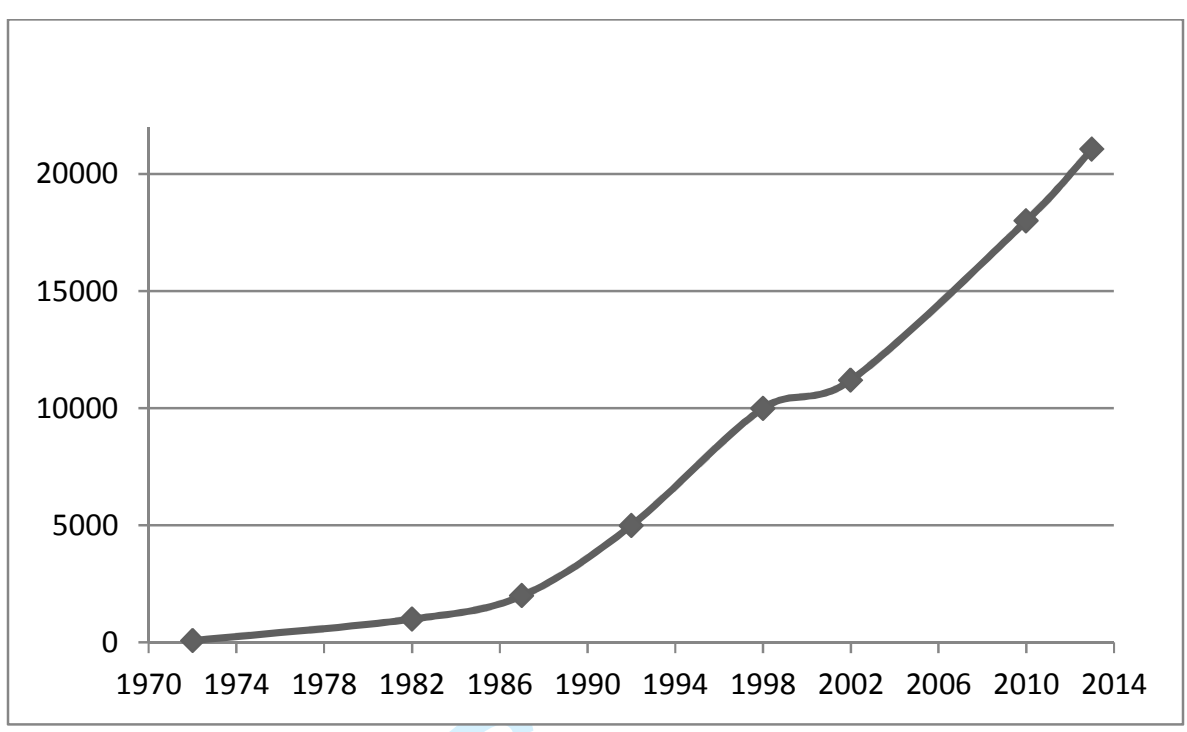

1

2

3

4

5

6

7

10

11

12

13

14

15

16

17

18

19

20

21

22

23

24

25

26

27

28

29

30

31

32

33

34

35

36

37

38

39

40

41

42

43

44

45

46

47

48

49

50

51

52

53

54

55

56

57

58

59

60 
Table 1. Professional Logics at play within APM

\begin{tabular}{|c|c|c|}
\hline & Collegial Professionalism & Corporate Professionalism \\
\hline \multirow[t]{2}{*}{$\begin{array}{l}\text { Mode of } \\
\text { Professionalisation }\end{array}$} & $\begin{array}{l}\text { Closure regimes supported by } \\
\text { mastery of formal body of } \\
\text { knowledge }\end{array}$ & $\begin{array}{l}\text { Proactive engagement with } \\
\text { organizations and markets and } \\
\text { ability to add value to users }\end{array}$ \\
\hline & Public good & $\begin{array}{l}\text { Commercial value added and } \\
\text { technical expertise }\end{array}$ \\
\hline Model & $\begin{array}{l}\text { Established professions like } \\
\text { engineering. }\end{array}$ & $\begin{array}{l}\text { New forms of managerial } \\
\text { specialisms and knowledge based } \\
\text { occupations }\end{array}$ \\
\hline Stakeholder Focus & State, members and wider society & $\begin{array}{l}\text { Domestic and multinational } \\
\text { corporations }\end{array}$ \\
\hline \multirow{5}{*}{$\begin{array}{l}\text { Occupational } \\
\text { Closure and } \\
\text { Membership }\end{array}$} & Single-tier membership & Multi-level membership structure \\
\hline & Individual membership & $\begin{array}{l}\text { Individual and organizational } \\
\text { membership }\end{array}$ \\
\hline & $\begin{array}{l}\text { Knowledge domain captured in } \\
\text { abstract body of knowledge, tested } \\
\text { by written examination. }\end{array}$ & $\begin{array}{l}\text { Co-production of situated } \\
\text { knowledge with industry, focus on } \\
\text { competences. }\end{array}$ \\
\hline & $\begin{array}{l}\text { Professional association regulates } \\
\text { ability to practice. }\end{array}$ & $\begin{array}{l}\text { Qualification embedded in } \\
\text { corporate procurement and } \\
\text { recruitment policies. }\end{array}$ \\
\hline & Supported by royal charter. & Not licensed/regulated. \\
\hline $\begin{array}{l}\text { Geographical } \\
\text { Jurisdiction }\end{array}$ & National & International \\
\hline
\end{tabular}

